Journal of Conflict \& Security Law (C) Oxford University Press 2010; all rights reserved. For permissions, please e-mail: journals.permissions@oxfordjournals.org

doi: $10.1093 /$ jcsl/krq011

Advance Access published on August 11, 2010

\title{
An Enduring Occupation: The Status of the Gaza Strip from the Perspective of International Humanitarian Law
}

\author{
Shane Darcy* and John Reynolds**
}

\begin{abstract}
The status of the Gaza Strip as occupied territory has been the subject of renewed policy, judicial and academic debate following a series of noteworthy developments in the territory since 2005. This article considers the present status of Gaza from the perspective of international humanitarian law in light of these events, which include Israel's 'disengagement' from the Gaza Strip in 2005, its declaration of Gaza as a 'hostile territory' in 2007, and the military action labelled 'Operation Cast Lead' which commenced in late 2008. It addresses the concept of occupation and the application of the laws of belligerent occupation, making recourse to the travaux préparatoires of relevant treaties, and international and national jurisprudence. In focusing on the situation in the Gaza Strip, the article assesses the various criteria identified in customary international law for determining the existence of a situation of occupation.
\end{abstract}

\section{Introduction}

The Israeli-Palestinian conflict has frequently given rise to challenging questions of international law, as well as to debate on the role of law and legal institutions in regulating the conflict. Like the conflict itself, every fine detail of law is vigorously contested, with an extensive array of legal rules implicated. Since the Israeli occupation of the West Bank and Gaza Strip was instituted in 1967, there have been fractious disputes regarding issues such as the application of international humanitarian law to the occupied territories, the lawfulness of territorial annexation therein, the extent of a State's human rights obligations extraterritorially, the legality of colonial-type settlements and separation walls in occupied territory, and the scope of a State's right to self-defence. Extensive analysis has been conducted with regard to the effects on various matters of law of an unusually prolonged belligerent occupation, ${ }^{1}$ with discussion also

* LLM, PhD, Lecturer, Irish Centre for Human Rights, National University of Ireland, Galway.

** LLM, Government of Ireland Scholar, NUI Travelling Scholar and PhD Candidate, Irish Centre for Human Rights, National University of Ireland, Galway. The authors would like to thank Kathleen Cavanaugh, Noam Lubell, Ray Murphy, and the Journal's reviewers for their helpful comments.

${ }^{1}$ See eg E Playfair (ed) International Law and the Administration of Occupied Territories (OUP, Oxford 1992). 
converging around the legality of Israel's continuing occupation itself and of the characteristics it may have assumed. ${ }^{2}$

Most recently, 'Operation Cast Lead', launched by the Israeli military against the Gaza Strip in December 2008, has given rise to an unprecedented level of debate on issues pertaining to war crimes and crimes against humanity, the doctrine of proportionality and the legality of the use of force under the UN Charter; extending well beyond circles of legal academia and practice to the mainstream media and public domain. ${ }^{3}$

The question of whether the Gaza Strip may be considered as occupied territory for the purposes of international humanitarian law, an issue which was the subject of much debate in the aftermath of Israel's 'disengagement' from the territory in $2005,{ }^{4}$ has again come to the fore and remains a disputed issue amongst parties to the conflict and other relevant actors. In the aftermath of 'Operation Cast Lead', the Israeli government stated that:

the Gaza Strip is neither a State nor a territory occupied or controlled by Israel. In these sui generis circumstances, Israel as a matter of policy ap-

${ }^{2}$ See eg O Ben-Naftali, AM Gross and K Michaeli, 'Illegal Occupation: Framing the Occupied Palestinian Territory' (2005), 23 Berkeley J Intl L 551; 'Occupation, Apartheid, Colonialism? A Re-assessment of Israel's Practices in the Occupied Palestinian Territories under International Law' (Human Sciences Research Council, Cape Town 2009).

3 By way of example, see the Guardian's extensive 'Gaza War Crimes Investigation' coverage and analysis at http://www.guardian.co.uk/world/series/gaza-war-crimesinvestigation. See also eg S Erlanger, 'Weighing Crimes and Ethics in Urban Warfare' New York Times (New York 17 January 2009); M Paulin, 'Self-Defence is no Defence' Guardian (London 21 January 2009) $\mathrm{CiF}<$ http://www.guardian.co.uk/commentisfree/ 2009/jan/21/gaza-humanrights>; M Mandell, 'Self-Defence Against Peace: Did SelfDefence Justify Israel's War on Gaza?' CounterPunch (Washington DC 5 February 2009) <http://www.counterpunch.com/mande102052009.html>; RA Stoil, 'Israeli NGO: Try Hamas for War Crimes' Jerusalem Post (Jerusalem 23 January 2009); T Zarchin, 'IDF: War Crime Charges over Gaza Offensive are "Legal Terror"' Ha'aretz (Israel 19 February 2009); R Falk, 'Israel's War Crimes' Le Monde Diplomatique (3 March 2009); S Milne, 'Will Israel be Brought to Book' Guardian (London 23 March 2009) $\mathrm{CiF}<\mathrm{http} / / /$ www.guardian.co.uk/commentisfree/2009/mar/23/israel-gaza>; A Hass, 'Time to Believe Gaza War Crimes Allegations' Ha'aretz. (Israel 24 March 2009); G Bisharat, 'Changing the Rules of War' San Francisco Chronicle (San Francisco 1 April 2009).

${ }^{4}$ See eg I Scobbie, 'An Intimate Disengagement: Israel's Withdrawal from Gaza, the Law of Occupation and of Self-Determination' (2004-5) 11 Ybk Islamic Middle Eastern L 3; Y Shany, 'Faraway, so Close: The Legal Status of Gaza after Israel's Disengagement' (2005) 8 Ybk Intl Humanitarian L 369; M Mari, 'The Israeli Disengagement from the Gaza Strip: An End of the Occupation?' (2005) 8 Ybk Intl Humanitarian L 356; G Aronson, 'Issues Arising from the Implementation of Israel's Disengagement from the Gaza Strip' (2005) 34(4) J Palestine Studies 49; N Rostow, 'Gaza, Iraq, Lebanon: Three Occupations under International Law' (2007) 37 Israel Ybk Human Rights 205. 
plies to its military operations in Gaza the rules of armed conflict governing both international and non-international armed conflicts. ${ }^{5}$

The relevant organs of the United Nations take a contrary view and hold that Gaza is occupied territory. ${ }^{6}$ The findings in the recent report of the United Nations Fact Finding Mission on the Gaza Conflict (the 'Goldstone Report') in this regard were unequivocal:

Israel has without doubt at all times relevant to the mandate of the Mission exercised effective control over the Gaza Strip. The Mission is of the view that the circumstances of this control establish that the Gaza Strip remains occupied by Israel. ${ }^{7}$

This assertion mirrors the conclusion of an 'Independent Fact-Finding Committee on Gaza', which held that 'Gaza remains occupied territory and that Israel is obliged to comply with the Fourth Geneva Convention in its actions in Gaza'.

The debate over the territory's status has been further fuelled by the labelling of Gaza as a 'hostile territory' by the Israeli government in $2007^{9}$ and by the recent attempt by the Palestinian National Authority to accept the jurisdiction of the International Criminal Court in light of allegations of war crimes committed during 'Operation Cast Lead'. ${ }^{10}$

5 Israel Ministry of Foreign Affairs, 'The Operation in Gaza, 27 December 2008-18 January 2009: Factual and Legal Aspects' (July 2009) 11 [footnote omitted] <http:// www.mfa.gov.il/NR/rdonlyres/E89E699D-A435-491B-B2D0-017675DAFEF7/0/ GazaOperationwLinks.pdf>.

${ }^{6}$ See eg United Nations Security Council (UNSC) Res 1860 (8 January 2009) S/RES/ 1860; United Nations General Assembly (UNGA) Res 63/96 (18 December 2008) A/ RES/63/96; Human Rights Council Resolution S-9/1 (12 January 2009) A/HRC/S-9/L.1; 'Report of the United Nations High Commissioner for Human Rights on the implementation of the Human Rights Council resolution S-9/1, The Grave Violations of Human Rights in the Occupied Palestinian Territory, Particularly due to the Recent Israeli Military Attacks against the Occupied Gaza Strip' (13 August 2009) A/HRC/12/37.

7 'Report of the United Nations Fact Finding Mission on the Gaza Conflict' (15 September 2009) UN Doc. A/HRC/12/48, 85 para 276.

8 --, 'Report of the Independent Fact-Finding Committee on Gaza: No Safe Place' (presented to the League of Arab States 30 April 2009) 16. A Spanish court exploring issues of alleged Israeli war crimes under the principle of universal jurisdiction has similarly held that Gaza constitutes occupied territory. See S Weill, 'The Targeted Killing of Salah Shehadeh: From Gaza to Madrid' (2009) 7 J Intl Crim Justice 617, 631.

${ }^{9}$ Israel Ministry of Foreign Affairs, 'Security Cabinet Declares Gaza Hostile Territory' (Press Release 19 September 2007) <http://www.mfa.gov.il/MFA/Government/ Communiques/2007/Security+Cabinet+declares+Gaza+hostile+territory+19-Sep2007.htm>. See also C Urquhart, 'Israel Declares Gaza Strip Hostile Territory' Guardian (London 20 September 2007) 22. In addition to 'hostile territory', Israeli government officials have on occasion used the term 'enemy entity' in this context.

10 Palestinian National Authority Ministry of Justice, 'Declaration Recognizing the Jurisdiction of the International Criminal Court' (21 January 2009). 
The designation of Gaza as occupied territory or otherwise is key to deciphering the legal regime that is applicable to the territory, the extent of Israel's obligations under international law towards the inhabitants of the territory, and may also be of relevance in any proceedings seeking to enforce humanitarian law by addressing alleged war crimes through international criminal law. This article addresses the question of whether Gaza may be considered as occupied territory under international humanitarian law, taking account of these more recent developments and debates regarding the territory. In considering the status of Gaza, the article does not seek to address the not unrelated question of whether Gaza, together with the West Bank, can be considered as a recognizable State under international law. ${ }^{11}$

The article begins with a consideration of the concept of occupation under international humanitarian law and the question of the application of the laws of belligerent occupation. Recourse is made to the travaux préparatoires of treaties that have addressed the question of occupation, as well as to relevant jurisprudence on this issue, including case-law of the International Court of Justice (ICJ) and the International Criminal Tribunal for the former Yugoslavia (ICTY). In looking at the situation of Gaza, the article addresses briefly the approach that Israel has taken towards the territory since 1967, including the questions of de jure and de facto applicability of international humanitarian law, as well as outlining the facts and legal developments surrounding the 'Disengagement Plan', the 'hostile territory' declaration and 'Operation Cast Lead'.

\section{Humanitarian Law and the Concept of Occupation}

International humanitarian law is the body of international law that seeks to regulate conduct in times of armed conflict. ${ }^{12}$ Often referred to as the laws of war or the laws of armed conflict, international humanitarian law is one of the oldest codified branches of international law. The obligations accruing to States under humanitarian law only arise as a general rule in the context of an armed conflict. An authoritative statement by the ICTY on the meaning of armed conflict provides that 'an armed conflict exists whenever there is a resort to armed force between States or protracted armed violence between governmental authorities and organized armed groups or between such groups within a State'. ${ }^{13}$ The Tribunal also stated in the seminal Tadic (Interlocutory Appeal) decision that:

${ }^{11}$ For more on this question, see J Quigley, 'The Palestine Declaration to the International Criminal Court: The Statehood Issue' (2009) 35 Rutgers L Records; FA Boyle, 'The Creation of the State of Palestine' (1990) 1 EJIL 301; J Crawford, 'The Creation of the State of Palestine: Too Much Too Soon?' (1990) 1 EJIL 307.

12 See generally F Kalshoven and L Zegveld, Constraints on the Waging of War; An Introduction to International Humanitarian Law (ICRC, Geneva 2001).

13 Prosecutor $v$ Tadic (Appeals Chamber, Decision on the Defence Motion for Interlocutory Appeal on Jurisdiction) ICTY-9-1-AR72 (2 October 1995) para 70. 
International humanitarian law applies from the initiation of such armed conflicts and extends beyond the cessation of hostilities until a general conclusion of peace is reached; or, in the case of internal conflicts, a peaceful settlement is achieved. Until that moment, international humanitarian law continues to apply in the whole territory of the warring States or, in the case of internal conflicts, the whole territory under the control of a party, whether or not actual combat takes place there. ${ }^{14}$

The existence of an armed conflict is needed to trigger the application of international humanitarian law, but its continued application can extend beyond the conclusion of actual hostilities.

Within the body of international humanitarian law there exists a specific category of laws which deal with situations of military occupation. The existence of occupation, which is largely a factual finding, triggers the application of the specific laws of occupation which are found primarily in the Hague Regulations of $1907^{15}$ and in Part III of the Fourth Geneva Convention of 1949. ${ }^{16}$ Some basic guidance as to what constitutes a military occupation is found in Article 42 of the Hague Regulations:

Territory is considered occupied when it is actually placed under the authority of the hostile army. The occupation extends only to the territory where such authority has been established and can be exercised.

Under the laws of occupation, an occupying power has a number of essential obligations aimed at ensuring that life in the occupied territory continues as normally as is possible, derived from the fact that during such a situation the previous government has been ousted. ${ }^{17}$ Article 43 of the Hague Regulations speaks of 'the authority of the legitimate power having in fact passed into the hands of the occupant', and stipulates that the latter shall 'take all the measures in his power to restore, and ensure, as far as possible, public order and safety'. ${ }^{18}$ The occupying power must also respect the laws in force in the country and ensure the respect of family honour and rights, the lives of persons, private property and religious convictions and practice. ${ }^{19}$ An occupying power has certain positive obligations also, such as the duty under the Fourth Geneva Convention

14 Tadic (n 13).

15 Regulations annexed to Hague Convention IV Respecting the Laws and Customs of War on Land (1907).

${ }^{16}$ Geneva Convention IV Relative to the Protection of Civilian Persons in Time of War (1949, entered into force 21 October 1950) 75 UNTS 287.

17 See generally Y Arai-Takahashi, The Law of Occupation (Martinus Nijhoff, Dordrecht 2009); Y Dinstein, The International Law of Belligerent Occupation (CUP, Cambridge 2009).

18 The authentic French text used the phrase 'l'ordre et la vie publics', which should have been translated into English as 'public order and civil life'. See EH Schwenk, 'Legislative Power of the Military Occupant Under Article 43, Hague Regulations' (1945) 54 Yale LJ 393 fn 1.

19 See eg Hague Regulations (1907) art 42-46. 
of 'ensuring the food and medical supplies of the population' ${ }^{20}$ It bears stating that occupations can vary from peaceful or benign ones to more volatile situations where occupying forces and resistance movements engage in hostilities, or where unlawful force is used against the occupied population itself. ${ }^{21}$

Occupation itself should be considered as a temporary situation, 'a transitional period following invasion and preceding the agreement on the cessation of the hostilities'. ${ }^{22}$ That being said, the drafters of the Geneva Conventions, bearing in mind the often protracted nature of peace negotiations, provided for the continuation of specific obligations of an occupying power after the 'general close of military operations'. ${ }^{23}$ Once an occupier still 'exercises the function of government in such territory', a number of provisions of the Geneva Conventions continue to apply. ${ }^{24}$ A significant development in recent years that is of particular relevance has been the recognition of the increasing role of human rights law in times of armed conflict. ${ }^{25}$ Very often the 'effective control' exercised by an occupying power over a population in occupied territory will also give rise to various obligations of that State under international human rights law. The ICJ has stated that 'the protection of the International Covenant on Civil and Political Rights does not cease in times of war'26 and, notably, it held in its judgment in Democratic Republic of Congo v Uganda that Uganda had human rights obligations in those parts of the DRC where it could be considered an occupying power. $^{27}$

While the existence of an armed conflict is sufficient to trigger the application of general rules of international humanitarian law, the additional conditions required for the specific laws of belligerent occupation to apply are to be found in Article 42 of the Hague Regulations and customary international humanitarian

${ }^{20}$ Fourth Geneva Convention (GC IV) (1949) art 55.

${ }^{21}$ See 'Report of the Expert Meeting on the Right to Life in Armed Conflicts and Situations of Occupation' (International Conference Centre, Geneva 1-2 September 2005) $<\mathrm{http}$ //www.ucihl.org/communication/Right_to_Life_Meeting_Report.pdf $>$.

22 Prosecutor v Naletilić et al (Judgment, Trial Chamber) ICTY-98-34-T (31 March 2003) para 214.

23 GC IV, art 6.

24 These are arts 1-12, 27, 29-34, 47, 49, 51, 52, 53, 59, 61-77, 143 of GC IV.

25 See eg F Coomans and M Kamminga (eds), Extraterritorial Application of Human Rights Treaties (Intersentia, Antwerp 2004); S Darcy, 'Human Rights Protection during the "War on Terror"; Two Steps Back, One Step Forward' (2007) 16 Minnesota J Intl L 2 353-70; WA Schabas, 'Lex specialis? Belt and Suspenders? The Parallel Operation of Human Rights Law and the Law of Armed Conflict, and the Conundrum of jus ad bellum' (2007) 40 Israel L Rev 592; O Ben-Naftali and Y Shany, 'Living in Denial: The Application of Human Rights in the Occupied Territories' (2003) 37 Israel L Rev 17; F Hampson, 'Human Rights and Humanitarian Law in Internal Conflicts' in MA Meyer (ed), Armed Conflict and the New Law (British Institute of International and Comparative Law, London 1989).

${ }^{26}$ Legality of the Threat or Use of Nuclear Weapons (Advisory Opinion) [1996] ICJ Rep 225 (8 July 1996) General List No 95 para 25.

27 Case Concerning Armed Activities on the Territory of the Congo (Democratic Republic of the Congo v Uganda) [2005] ICJ Rep 168 (19 December 2005) General List No 116 para 175. 
law. Article 42, itself a rule of customary international law, ${ }^{28}$ speaks of an occupation existing where the actual authority of a hostile army over territory has been established and is capable of being exercised. Many of the Allied occupations in the aftermath of the Second World War, for example, would have fulfilled these criteria. ${ }^{29}$ The drafting history of the Hague Regulations illuminates further the types of situation which the provision was intended to cover.

The genesis of Article 42 of the Hague Regulations lay in an earlier document, the Project of an International Declaration concerning the Laws and Customs of War, the so-called Brussels Declaration of $1874 .{ }^{30} \mathrm{~A}$ first draft of the relevant provision had stated:

A territory belonging to one of the belligerents is considered as occupied when it is placed actually under the authority of the hostile army.

The occupation only extends to those territories where this authority is established and lasts only so long as it can be exercised. ${ }^{31}$

Participants in this endeavour devoted considerable time to the meaning of belligerent occupation and the question of when such was established. On the issue of the power of an occupier, Baron Lambermont, the Belgian delegate, stated that 'the means of exercising it must be real and sufficient, a question which also presents great difficulties'. He questioned the extent to which resistance must have ceased, in order that this power may be considered established, adding that '[o]ccupation is not generally speaking established all at once; resistance is at times more or less prolonged, and only dies out insensibly or partially' ${ }^{32}$ Another delegate, General de Voigts-Rhetz of Germany, contended that 'generally speaking, the occupying Power may be considered practically established when the population is disarmed, either by giving up its arms; or by having them taken from them, or again when flying columns are traversing the country and establishing relations with local authorities'. ${ }^{33}$ Baron Jomini, the delegate of Russia, made the observation that if the occupier is in a position to exercise his authority, the occupation is a reality; from the moment that this power no longer exists, the occupation ceases'. 34

28 See Judgment and Sentences of the Nuremberg International Military Tribunal 1 October 1946 (1947) 41 AJIL 1, 172, 248-9.

29 See E Benvenisti, The International Law of Occupation (Princeton University Press, Princeton 2004) 72-96.

30 Art 1, Project of an International Declaration concerning the Laws and Customs of War (Brussels 27 August 1874).

31 --, 'Correspondence Respecting the Proposed Conference at Brussels on the Rules of Military Warfare' (United Kingdom Parliamentary Papers) Miscellaneous No 1 (1875) 202.

32 Ibid 237-8.

33 Ibid 238.

34 Ibid 259. 
In the deliberations on the wording of the relevant provision of the Brussels Declaration, some attempts of relevance were made to change the last phrase of the second sentence. Colonel Staaf, for Sweden and Norway, had proposed to substitute it with the phrase 'lasts only so long as it is exercised in an effective manner'. ${ }^{35}$ It was felt that this text would more clearly emphasize the analogy between occupation and the concept of blockade. ${ }^{36}$ The delegates ultimately did not accept this proposal and in fact also decided to remove the words 'lasts so long as', as had initially been proposed. However, as the interaction between the Russian and Swiss delegates made clear, this rewording did not change the meaning to be attached to the particular phrase, indicating that in fact an occupation existed only to the extent that it could be exercised. ${ }^{37}$ The precise meaning of the phrase was an issue which arose again at the Hague Peace Conferences leading to the adoption of the 1907 Hague Regulations.

While the participants at the 1899 Hague Peace Conference did in the end unanimously adopt verbatim the text from Article 1 of the Brussels Declaration, ${ }^{38}$ there was a proposal during the proceedings to delete the second sentence, in order to provide for cases in which 'a belligerent has effectively established his authority in a territory, but in which communications... are interrupted and in which uprisings occur in that territory and are momentarily successful'. ${ }^{39}$ This was viewed as being too expansive because an occupation 'can be recognized only when the authority of the belligerent is actually established'. ${ }^{40}$ Referring to the more restrictive definition in Article 41 of the Institute of International Law's Oxford Manual ('Territory is regarded as occupied when, as the consequence of invasion by hostile forces, the State to which it belongs has ceased, in fact, to exercise its ordinary authority therein, and the invading State is alone in a position to maintain order there. The limits within which this state of affairs exists determine the extent and duration of the occupation.'), one participant stated that it would be 'impossible to recognize an occupation which does not exist'. ${ }^{41}$ Another explained that from a military standpoint, 'an army considers a territory occupied when it finds itself therein either with the bulk of its troops or with detachments, and when the lines of communication are insured'. ${ }^{42}$ Colonel Gilinsky, of Russia, added that an uprising may occur, but 'the fact of such an uprising breaking out does not prevent the occupation from being considered as actually existing' and refers to what he sees as an explanation of the Brussels text, that the occupier must be 'in a position to cope with the army of

35 Ibid.

${ }^{36}$ Ibid.

37 Ibid.

38 See Second Commission: Second Subcommission, Seventh Meeting, 8 June 1899 in $\mathrm{J}$ Brown Scott and Carnegie Endowment for International Peace, The Proceedings of the Hague Peace Conferences, Translation of the Official Texts: The Conference of 1899 (OUP, New York 1920) 509-12.

39 Ibid 509 (Colonel Gross von Schwarzhoff, Germany).

40 Ibid 509-10 (General den beer Poortugael, The Netherlands).

41 Ibid 510 (Chevalier Descamps, Belgium).

42 Ibid 510 (Colonel Gilinsky, Russia). 
the occupied territory and the uprisings of the population'. ${ }^{43}$ Another delegate stated that ' $[\mathrm{w}]$ hen an authority has not power enough to maintain itself, it is not established and there is no occupation', ${ }^{44}$ and it was noted how the Brussels text had been subject to 'thorough deliberations' at the time of that conference. ${ }^{45}$

The parallel between blockade and occupation is something which was also highlighted by legal scholars writing in the aftermath of the adoption of the Hague Regulations. TJ Lawrence wrote in 1917 that 'belligerent occupation implies, first firm possession so that the occupying power has the country under its control and can exercise its will therein, and secondly a continuance of the war, so that the invader has not become the sovereign'. ${ }^{46}$ He opined that:

occupation on land is analogous to blockade at sea; and as blockades are not recognized unless they are effective, so occupation must rest on effective control. Its rights are founded on mere force, and therefore they cannot extend beyond the area of available force. But the force need not be actually on the spot. The country embraced within the invader's lines may be very extensive, and the bulk of his troops will, of course, be found on its outer edge opposing the armies of the invaded state. Any territory covered by the front of the invaders should be held to be occupied, but not territory far in advance of their main bodies. The fact that it is penetrated here and there by scouts and advance guards does not bring it under firm control, and therefore cannot support a claim to have deprived the invaded state of all authority therein. But the rights of occupancy, once acquired, remain until the occupier is completely dispossessed. ${ }^{47}$

In considering the criteria for occupation, JM Spaight placed emphasis on the need for military government, the presence of military forces on the territory or 'within reach' to maintain power. ${ }^{48} \mathrm{He}$ contended that 'while a commander is not required to picket the whole country and to garrison every hamlet, in order to establish his occupation, he must not proclaim as occupied a territory in which his troops have not, and could not, set foot' ${ }^{49}$ Spaight wrote that the occupying power must 'police the country and have it firmly under control'. ${ }^{50} \mathrm{He}$ also made the comparison with blockade:

To establish an effective blockade there need not be a line of cruisers drawn across the mouth of a harbour, but there must be some force within

43

${ }^{44}$ Ibid 510 (General den beer Poortugael, The Netherlands).

45 Ibid 511.

46 TJ Lawrence, The Principles of International Law (6th edn Macmillan \& Co., London 1917) 435-6.

47 Ibid.

48 JM Spaight, War Rights on Land (MacMillan \& Co, London 1911) 327.

49 Ibid.

50 Ibid 328 [original emphasis]. 
striking distance, so as to make it difficult for any vessel to 'run the blockade' and gain entrance; and the same principle governs occupation, [...] If the occupying belligerent is displaced by the return of the national forces, or if he retires definitely, of his own accord, the occupation ceases. ${ }^{51}$

The aftermath of the Second World War provided the first occasion for judicial consideration of the existing provisions of the laws of war concerning the meaning of occupation, and in the so-called Hostages case, a United States Military Tribunal observed that:

The question of criminality in many cases may well hinge on whether an invasion was in progress or an occupation accomplished. Whether an invasion has developed into an occupation is a question of fact. The term invasion implies a military operation while an occupation indicates the exercise of governmental authority to the exclusion of the established government. This presupposes the destruction of organised resistance and the establishment of an administration to preserve law and order. To the extent that the occupant's control is maintained and that of the civil government eliminated, the area will be said to be occupied. ${ }^{52}$

With regard to Germany's actions in Yugoslavia, the government there had capitulated nine days after the invasion, 'the powers of government passed into the hands of the German armed forces and Yugoslavia became an occupied territory'. ${ }^{53}$ Once this had happened, the recouping of partial control by local partisans would not suffice to abrogate the existence of occupation. Discussing the resistance movement which had 'assumed the appearance of a military campaign' in the occupied territories, the Tribunal stated:

It is clear that the German armed forces were able to maintain control of Greece and Yugoslavia until they evacuated them in the fall of 1944. While it is true that the partisans were able to control sections of these countries at various times, it is established that the Germans could at any time they desired assume physical control of any part of the country. The control of the resistance forces was temporary only and not such as would deprive the German Armed Forces of its status of an occupant. ${ }^{54}$

The Tribunal held that its findings were 'consistent with Article 42 of the Hague Regulations'. 55

51 Ibid 328-9.

52 United States of America $v$ Wilhelm List et al (Judgment) Case No 7 (19 February 1948) XI Trials of War Criminals before the Nürnberg Military Tribunals under Control Council Law No 10, 757, 1243.

53 Ibid.

54 Ibid.

55 Ibid 1244. 
Neither the Fourth Geneva Convention of 1949 nor Additional Protocol I of 1977 depart from the definition of occupation provided in the Hague Regulations. That said, in addition to a greater range of provisions regulating the relationship between an occupying power and a local population, a broader protection is granted to civilians by the Fourth Convention by emphasising that such persons are protected as soon as they fall into the hands of a Party to the conflict or an Occupying Power 'of which they are not nationals'. ${ }^{56}$ In addressing the personal scope of the treaty, the Commentary to the Fourth Geneva Convention notes that 'occupation' as used in this context:

has a wider meaning than it has in Article 42 of the Regulations annexed to the Fourth Hague Convention of 1907. So far as individuals are concerned, the application of the Fourth Geneva Convention does not depend upon the existence of a state of occupation within the meaning of Article 42 [...]. The relations between the civilian population of a territory and troops advancing in to a territory, whether fighting or not, are governed by the present Convention. There is no intermediate period between what might be termed the invasion phase and the inauguration of a stable regime of occupation. ${ }^{57}$

Article 6 of the Fourth Geneva Convention, which specifies those provisions of the treaty which continue to apply in occupied territory after the general close of military operations, states that the Occupying Power will be bound by such provisions 'for the duration of the occupation, to the extent that such Power exercises the functions of government in such territory'.

Contemporary international jurisprudence continues to rely on Article 42 of the Hague Regulations as the standard for determining the presence of an occupation. ${ }^{58}$ In its judgment in Democratic Republic of Congo $v$ Uganda, the International Court of Justice found that Uganda was an occupying power in those parts of the DRC where its armed forces were stationed and had 'substituted their own authority for that of the Congolese Government', even if a structured military administration had not been established there. ${ }^{59}$ The Court held that an occupying power's obligations under Article 43 of the Hague Regulations 'comprised the duty to secure respect for the applicable rules of international human rights law and international humanitarian law, to protect the inhabitants of the occupied territory against acts of violence, and not to tolerate such violence by any third party, ${ }^{60}$

56 See GC IV arts 2, 4 and 6.

57 J Pictet (ed), Commentary; IV Geneva Convention, Relative to the Protection of Civilian Person in Times of War (ICRC, Geneva 1958) 60.

58 See eg ICJ, Legal Consequences of the Construction of a Wall in the Occupied Palestinian Territories (Advisory Opinion) (9 July 2004) General List No 131 para 78; Democratic Republic of the Congo v Uganda (n 27) para 172: 'The Court observes that, under customary international law, as reflected in Art 42 of the Hague Regulations of 1907 , territory is considered to be occupied when it is actually placed under the authority of the hostile army'.

59 Democratic Republic of the Congo v Uganda (n 27) para 173.

60 Ibid para 178. 
International humanitarian law treaties, their travaux préparatoires, academic commentary and judicial decisions have viewed occupation as existing where there is effective control over territory by a hostile army and involving usually the presence of troops, some sort of military government or administration and the exclusion of the previous government. The ICTY has provided some useful guidelines for determining the existence of an occupation under Article 42 of the Hague Regulations, noting that such requires '[a] further degree of control' than that needed to say that an armed conflict exists. ${ }^{61}$ Drawing on the existing conventional and customary international law, and some examples of State practice, the ICTY points to the following criteria in order to establish 'whether the authority of the occupying power has actually been established':

- the occupying power must be in a position to substitute its own authority for that of the occupied authorities, which must have been rendered incapable of functioning publicly;

- the enemy's forces have surrendered, been defeated or withdrawn. In this respect, battle areas may not be considered as occupied territory. However, sporadic local resistance, even successful, does not affect the reality of occupation;

- the occupying power has a sufficient force present, or the capacity to send troops within a reasonable time to make the authority of the occupying power felt;

- a temporary administration has been established over the territory;

- the occupying power has issued and enforced directions to the civilian population. ${ }^{62}$

This is an authoritative summation of the criteria relevant for finding the existence of a belligerent occupation, although it should be noted that the ICTY does not specify that all such criteria must be satisfied for a situation of occupation to be said to exist. ${ }^{63}$ Israel would have satisfied many of these criteria vis-à-vis Gaza up to 2005, and the following section will assess whether the same can be said since that time.

61 Naletilić et al (n 22) para 214.

${ }^{62}$ Ibid para 217 [footnotes omitted].

${ }^{63}$ It also bears noting that in order to ensure protection of civilians to the fullest extent possible, the ICTY affirms that that the application of the law of occupation to the civilian population under the GC IV differs from its application under Article 42 of the Hague Regulations. According to the Trial Chamber, "the application of the law of occupation as it effects "individuals" as civilians protected under Geneva Convention IV does not require that the occupying power have actual authority. For the purposes of those individuals' rights, a state of occupation exists upon their falling into "the hands of the occupying power." Otherwise civilians would be left, during an intermediate period, with less protection than that attached to them once occupation is established.' Ibid para 221. 


\section{Does Gaza Remain Occupied Territory under International Law?}

From the perspective of international humanitarian law, Israel's presence in the West Bank (including East Jerusalem) and Gaza Strip following the 1967 SixDay War was seen internationally as triggering the application of the rules and principles applicable to situations of belligerent occupation and this view has been reiterated in the four decades since by, for example, the United Nations Security Council and General Assembly, the International Committee of the Red Cross, the High Contracting Parties to the 1949 Geneva Conventions and the ICJ. ${ }^{64}$ The Israeli authorities, however, have sought to circumvent the full application of the Fourth Geneva Convention, despite their initial acceptance, ${ }^{65}$ by classifying the territories as 'administered ${ }^{66}$ or 'disputed', ${ }^{67}$ as opposed to occupied, and by claiming that the Israeli military would abide by the 'humanitarian provisions' of the Fourth Convention in the West Bank and Gaza, although the treaty itself would not apply formally. ${ }^{68}$ The contention that the Fourth Geneva Convention is not de jure applicable to the Palestinian territories because they were not under the sovereignty of a High Contracting Party to the Geneva Conventions ${ }^{69}$ has been resoundingly rejected by legal scholars in Israel $^{70}$ and beyond, ${ }^{71}$ as well as

${ }^{64}$ For a useful summation of this discussion see ICJ Wall Advisory Opinion (n 58) paras 86101.

65 Article 35 of Israeli Military Proclamation No 3, June 1967, stated that Israeli military courts in the occupied territory 'must apply the provisions of the [Fourth] Geneva Convention ... In case of conflict between this Order and the said Convention, the Convention shall prevail.'

${ }^{66}$ See M Shamgar, 'The Observance of International Law in the Administered Territories' (1971) 1 Israel Ybk Human Rights 262.

67 The official position of the Israeli government published in 2003 classified the West Bank and Gaza Strip as 'disputed, not occupied, territory'. See Israel Ministry of Foreign Affairs, 'Forgotten Facts About the West Bank and Gaza Strip' (February 2003) < http://www.mfa.gov.il/MFA/MFAArchive/2000_2009/2003/2/DISPUTED\% 20TERRITORIES-\%20Forgotten \%20Facts \%20About \%20the \%20We $>$.

${ }^{68}$ See eg Shamgar (n 66). Cf. D Kretzmer, The Occupation of Justice (SUNY Press, Albany 2002). The Israeli authorities have not clarified what they perceive to be the 'humanitarian provisions' of GC IV.

69 See YZ Blum, 'The Missing Reversioner: Reflections on the Status of Judea and Samaria' (1968) 3 Israel L Rev 279.

70 See eg Y Dinstein, 'The International Law of Belligerent Occupation and Human Rights' (1978) 8 Israel Ybk Human Rights 104, 107; T Meron, 'West Bank and Gaza: Human Rights and Humanitarian Law in the Period of Transition' (1979) 9 Israel Ybk Human Rights 106; Kretzmer, Occupation of Justice (n 68) 34.

71 See eg A Roberts, 'Prolonged Military Occupation: The Israeli-Occupied Territories since 1967', in Playfair (n 1) 61-70; H-P Gasser, 'Protection of the Civilian Population' in D Fleck (ed) Handbook of Humanitarian Law in Armed Conflict (OUP, Oxford 1995) 244. 
by the United Nations ${ }^{72}$ and the ICJ. ${ }^{73}$ The 'missing reversioner' argument has thus been invalidated as an erroneous interpretation of Article 2 of the Fourth Geneva Convention. The ICJ confirmed the view that the question of whether territory occupied during a conflict was under the sovereignty of one of the parties to the conflict is irrelevant to a determination of occupation for the purposes of the Convention. In this regard it is also worth noting that relevant terminology ("territory belonging to one of the belligerents" ${ }^{74}$ ) present in Article 1 of the aforementioned 1874 Brussels Declaration was dropped from the definition of occupation subsequently set down in Article 42 of the Hague Regulations.

Despite its stance on the Fourth Geneva Convention, the Government of Israel has accepted the application of the 1907 Hague Regulations, and judgments of the Israeli courts have confirmed at various stages that the framework governing the West Bank and Gaza is that of belligerent occupation and that relevant customary laws are to be applied. ${ }^{75}$ In the 1978 Beit El case, before the Israeli Supreme Court, sitting as the High Court of Justice, ${ }^{76}$ the Court said that the situation was 'one of belligerency, and the status of the respondents in respect of the occupied territory is that of an occupying power'. ${ }^{77}$ As recently as 2006, in the so-called Targeted Killings case, the Supreme Court recognized the existence of an armed conflict in Gaza and held that the laws of occupation were part of the normative framework which applied. ${ }^{78}$ In its judgment, the Court reiterated its view that customary rules of international law are part of Israeli law, including those rules in the 1977 Additional Protocol I to the Geneva Conventions of 1949, an instrument which Israel has not ratified. ${ }^{79}$ Up until at least December 2006, therefore, it had been recognized by the Israeli judiciary that the Gaza Strip, as well as the West Bank, was occupied territory in which Israel had the status of an occupying power, bound by the relevant rules of international humanitarian law.

72 See eg Illegal Israeli actions in Occupied East Jerusalem and the rest of the Occupied Palestinian Territory, UNGA Res ES-10/9 (20 December 2001) UN Doc. A/RES/ES/ 10-9; Security Council Resolution (UNSC Res) 1322 (7 October 2000) UN Doc. S/ RES/1322.

73 ICJ Wall Advisory Opinion (n 58) para 101.

${ }^{74}$ Emphasis added.

75 See generally Dinstein (n 17) 12-30; Benvenisti (n 29) 107-23.

76 Israel's Supreme Court fulfils a dual function: as the Supreme Court it acts as a court of appeal from the decisions of lower courts, while as the High Court of Justice it operates as a court of first and last instance in petitions for the review of the legality or constitutionality of the actions of the government and its agents. See generally Kretzmer (n 68) 10-11.

77 Ayyub v Minister of Defence (1978) 33 (2) PD 113, English summary in (1979) 9 Israel Ybk Human Rights 337, cited in Kretzmer, Occupation of Justice (n 68) 36.

78 The Public Committee against Torture in Israel et al v Government of Israel et al, HCJ 769/02 (13 December 2006) paras 16-23.

79 Ibid para 20. 


\section{A. 'Disengagement'}

The legal status of the Gaza Strip under international law became the subject of considerable scrutiny following the unilateral 'disengagement' by Israel from the territory in August-September $2005 .{ }^{80}$ Former Israeli Prime Minister Ehud Olmert had opined in 2003 that if circumstances enabling a serious negotiation between Israel and the Palestinians fail to develop, the only option will be a unilateral evacuation'. ${ }^{81}$ Amid much media attention, Israel withdrew all its military personnel from Gaza and evacuated the inhabitants of settlements there. ${ }^{82}$ The original official Israeli Government plan had stated that once this process had been completed, there would 'no longer be any permanent presence of Israeli security forces or Israeli civilians in the areas of Gaza Strip territory which have been evacuated' and, most importantly, '[a]s a result, there will be no basis for claiming that the Gaza Strip is occupied territory'. ${ }^{83}$ The Palestinian Negotiation Affairs Department responded at the time by saying that 'Israel will remain the Occupying Power of the Gaza Strip' given the extensive control maintained over the borders of Gaza, airspace and the coastal waters under the Disengagement Plan. ${ }^{84}$ Indicative of an intention to retain effective control, the text of the plan itself, as well as providing for an Israeli military presence on the border between Gaza and Egypt for an indeterminate period of time, ${ }^{85}$ did stipulate that:

80 See eg Scobbie (n 4); Shany (n 4); Mari (n 4).

81 C Levinson, 'Olmert: Gaza Disengagement Carried Out at the Right Time' Ha'aretz (Israel 9 September 2009).

82 G Myre, 'The Gaza Withdrawal: Acts of Defiance; Thousands of Settlers Remain in Gaza, Defying Israeli Orders; Military Moves In' New York Times (New York 15 August 2005) A9; S Erlanger, 'Last Settlers Leave Gaza Quietly, Ending a 40-Year Era' New York Times (New York 23 August 2005) A8; C Urquhart and C McGreal, 'Pullout of Israeli Settlers Complete' Guardian (London 24 August 2005). On the unlawfulness of these settlements, see eg ICJ Wall Advisory Opinion ( $n$ 58) para 120.

83 Israeli Ministry of Foreign Affairs, 'The Disengagement Plan - General Outline' (18 April 2004) Sections II.i.2 and 3, <http://www.mfa.gov.il/MFA/Peace+Process/ Reference+Documents/Disengagement+Plan+-+General+Outline.htm $>$. Significantly, this language was removed from the final definitive version of the plan that was approved by the Israeli Cabinet on 6 June 2004 and by the Knesset on 26 October 2004. See Israeli Ministry of Foreign Affairs 'Revised Disengagement Plan' (6 June $2004)<$ http://www.mfa.gov.il/MFA/Peace+Process/Reference+Documents/Revised + Disengagement+Plan+6-June-2004.htm $>$. Iain Scobbie cites reports that one of the reasons for this deletion was that the Israeli Cabinet had received legal advice to the effect that a claim to an end of the occupation could not be maintained while Israel retained control of the Gaza-Egypt border, and of Gaza's ports and airspace, Scobbie (n 4) 5.

84 See PLO Negotiation Affairs Department, 'The Israel "Disengagement" Plan: Gaza Still Occupied' (September 2005) <www.nad-plo.org/inner.php?view=disengagement_ Fact_GAZA \%20STILL\%20OCCUPIED>.

85 'General Outline' (n 83) Section VI. 
Israel will guard and monitor the external land perimeter of the Gaza Strip, will continue to maintain exclusive authority in Gaza air space, and will continue to exercise security activity in the sea off the coast of the Gaza Strip. ${ }^{86}$

Two years after the removal of settlements from the Gaza Strip and the end of the permanent presence of ground troops (although with several incursions involving ground troops having taken place during that period), ${ }^{87}$ the Israeli Government declared on 19 September 2007 that Gaza had become a 'hostile territory' under the control of Hamas. ${ }^{88}$ The term 'hostile territory' does not appear in any of the treaties of international humanitarian law, although the rationale for the designation of Gaza as such is apparent from the statement by the Ministerial Committee on National Security Issues, which demonstrated Israel's intention to impose sanctions on Gaza, particularly in relation to the supply of fuel and electricity, over which it had retained control following withdrawal:

Hamas is a terrorist organization that has taken control of the Gaza Strip and turned it into hostile territory. This organization engages in hostile activity against the State of Israel and its citizens and bears responsibility for this activity. In light of the foregoing, it has been decided to adopt the recommendations that have been presented by the security establishment, including the continuation of military and counter-terrorist operations against the terrorist organizations. Additional sanctions will be placed on the Hamas regime in order to restrict the passage of various goods to the Gaza Strip and reduce the supply of fuel and electricity. Restrictions will also be placed on the movement of people to and from the Gaza Strip. The sanctions will be enacted following a legal examination, while taking into account both the humanitarian aspects relevant to the Gaza Strip and the intention to avoid a humanitarian crisis. ${ }^{89}$

This statement suggests the implementation of punitive-type measures affecting the entire population of Gaza, and any assessment of their lawfulness requires consideration first of the relevant legal framework applicable to the situation in Gaza.

The Israeli Government has maintained its position from the time of 'disengagement' that Gaza is not occupied territory. The debate on this matter largely revolves around the level of control exercised over the Gaza Strip by Israel and the type and extent of control that is necessary for an occupation to be said to

86 Ibid Section III.i.1.

87 For example, 'Operation Summer Rain' commenced in July 2006, lasted for three months, and lead to the deaths of over 250 residents of Gaza and significant destruction of property. See United Nations Office for the Coordination of Humanitarian Affairs, occupied Palestinian territory, Gaza Strip Situation Report, 10 October $2006<$ http:// www.ochaopt.org/documents/GazaStrip_10Oct06.pdf>.

88 'Security Cabinet Declares Gaza Hostile Territory' (n 9).

89 Ibid. 
persist under international humanitarian law. On the one hand, it is clear that Israel no longer maintains a fixed military presence in the Gaza Strip, it is not fully administering or governing the territory and there may be some doubt as to whether the control exercised over Gaza is 'effective', given the launching of rocket attacks by Palestinian armed groups into Israel.${ }^{90}$ It could be argued that since the seizure of control by Hamas in June 2007, it is they who exercise effective control on the ground in Gaza and for Israel to reassert control would require a major ground offensive involving the likelihood of numerous casualties. On the other hand, Israel continues to exercise considerable control over this relatively small geographical area, through the control of airspace, coastal waters and borders, and through the dependence of Gaza's population and economy on Israel. ${ }^{91}$ Professor John Dugard, the former UN Special Rapporteur on the situation of Human Rights in the Palestinian Territories occupied since 1967, has outlined several factors demonstrating Israel's effective control over Gaza;

(a) Substantial control of Gaza's six land crossings: the Erez crossing is effectively closed to Palestinians wishing to cross to Israel or the West Bank. The Rafah crossing between Egypt and Gaza, which is regulated by the Agreement on Movement and Access entered into between Israel and the Palestinian Authority on 15 November 2005 (brokered by the United States, the European Union and the international community's envoy for the Israeli disengagement from Gaza), has been closed by Israel for lengthy periods since June 2006. The main crossing for goods at Karni is strictly controlled by Israel and since June 2006 this crossing too has been largely closed, with disastrous consequences for the Palestinian economy.

(b) Control through military incursions, rocket attacks and sonic booms: sections of Gaza have been declared 'no-go' zones in which residents will be shot if they enter.

(c) Complete control of Gaza's airspace and territorial waters.

(d) Control of the Palestinian Population Registry: the definition of who is 'Palestinian' and who is a resident of Gaza and the West Bank is controlled by the Israeli military. Even when the Rafah crossing is open, only holders of Palestinian identity cards can enter Gaza through the crossing; therefore control over the Palestinian Population Registry is also control over who may enter and leave Gaza. Since 2000, with few exceptions, Israel has not permitted additions to the Palestinian Population Registry. ${ }^{92}$

90 See A Bell, 'International Law and Gaza: The Assault on Israel's Right to Self-Defence' (January 2008) 7 Jerusalem Viewpoints 29.

91 See Mari (n 4) 366.

92 J Dugard, 'Human Rights in Palestine and Other Occupied Arab Territories, Report of the Special Rapporteur John Dugard on the Situation of Human Rights in the Palestinian Territories Occupied since 1967' (21 January 2008) UN Doc A/HRC/7/17 para 11. See also 'Statement by John Dugard, Special Rapporteur on the situation of human rights in the Occupied Palestinian Territories' (New York 24 October 2007). 
The dispute over the status of Gaza may in part be attributed to the increased obligations under international humanitarian law that are placed on a party to an armed conflict once they have assumed the status of an occupying power. A pertinent example of this is the provision of medical and food supplies for a civilian population. Article 23 of the Fourth Geneva Convention, which applies to all populations of the countries in conflict, obliges parties to an armed conflict to allow passage of such supplies:

Each High Contracting Party shall allow the free passage of all consignments of medical and hospital stores and objects necessary for religious worship intended only for civilians [...] It shall likewise permit the free passage of all consignments of essential foodstuffs, clothing and tonics intended for children under fifteen, expectant mothers and maternity.

In contrast, Article 55 of the Fourth Convention applies only to Occupied Territories and requires a party to provide such supplies:

To the fullest extent of the means available to it, the Occupying Power has the duty of ensuring the food and medical supplies of the population; it should, in particular, bring in the necessary foodstuffs, medical stores and other articles if the resources of the occupied territory are inadequate.

In the same vein, Article 69 of Additional Protocol I to the Geneva Conventions positively compels occupants to 'ensure the provision of clothing, bedding, means of shelter [and] other supplies essential to the survival of the civilian population of the occupied territory'; while Article 70 of the Protocol places substantially lesser requirements on non-occupying parties to an armed conflict to merely 'allow and facilitate rapid and unimpeded passage of all relief consignments'. ${ }^{93}$ This differential arises because an occupying power by definition exercises ultimate authority and assumes responsibilities accordingly, including that of ensuring that life continues as normally as possible in the occupied territory. ${ }^{94}$

\section{B. Judicial Scrutiny}

It was in relation to supplies necessary for the well-being of the population that the legal status of Gaza came under judicial scrutiny in the Israeli courts. Several Israeli and Palestinian human rights organizations took petitions concerning the heightened sanctions imposed on Gaza by Israel and serving to exacerbate the humanitarian crisis there following the 'hostile territory' declaration in 2007. In the Gaza Fuel and Electricity case, a collective of human rights groups asserted

93 Protocol Additional to the Geneva Conventions of 12 August 1949, and Relating to the Protection of Victims of International Armed Conflicts (Additional Protocol I) (1977, entered into force 7 December 1978) 1125 UNTS 3.

94 See eg Hague Regulations (1907) art 43. 
that Israel remained an occupying power in Gaza, with all the attendant legal obligations under the laws of occupation, and that the cutting of electricity and fuel supplies amounted to collective punishment. ${ }^{95}$ The Government of Israel argued that 'it no longer occupies the Gaza Strip in belligerent occupation, it has no obligation to supply fuel or electricity to the Gaza Strip beyond what is required to provide for the essential humanitarian needs of the civilian population therein'. ${ }^{96}$ The State recognized its obligations under Article 23 of the Fourth Geneva Convention, the similar rule in Article 70 of Additional Protocol I and the prohibition of starvation under Article 54 of the Protocol, but not the more extensive requirements under Article 55 of the Fourth Convention and Article 69 of the Protocol.

In a short judgment with the briefest legal reasoning, the Israeli Supreme Court ruled that Israel 'does not have a general duty to ensure the welfare of the residents of the Gaza Strip or to maintain public order in the Gaza Strip under all of the laws of a belligerent occupation under international law'. ${ }^{97}$ The court determined that:

since September 2005, Israel no longer has effective control over what happens in the Gaza Strip. The military government that was in force in this territory in the past was ended by a decision of the government, and Israeli soldiers are no longer stationed in the territory on a permanent basis, nor are they in charge of what happens there. [...] Neither does Israel have any effective ability, in its present position, of enforcing order and managing civilian life in the Gaza Strip. ${ }^{98}$

It bears repeating at this juncture that the same Supreme Court had held in the Targeted Killings case - with the majority judgment handed down by then President (Emeritus) Aharon Barak in December 2006, fifteen months post 'disengagement' - that the law applicable to the Gaza Strip 'includes the laws of belligerent occupation'. 99

Deviating from that precedent, the Court held in Gaza Fuel and Electricity that the obligations upon the Israeli State derived from the basic humanitarian needs of the residents of the Gaza Strip and that international humanitarian law 'requires them to allow the Gaza Strip to receive only what is needed in order to

95 Jaber al Bassiouni Ahmed et al v The Prime Minister and Minister of Defence (Petition for an Order Nisi and an Urgent Request for Injunction) HCJ 9132/07 (28 October 2007). English translation available at: http://www.adalah.org/eng/features/opts/petition\% 20-\%20english.doc.

96 Bassiouni Ahmed et al v Prime Minister (Ruling) HCJ 9132/07 (29 November 2007) para 2, English translation at <http://www.adalah.org/eng/features/opts/English\% 20Translation \%20of\%20HCJ9132\%20decision.doc>.

97 Bassiouni Ahmed et al v Prime Minister (Judgment) HCJ 9132/07 (30 January 2008) para 12.

98 Ibid.

99 Public Committee v Government of Israel (n 78) para 18. 
provide the essential humanitarian needs of the civilian population'. ${ }^{100}$ It was in light of this obligation to allow passage of essential supplies, and having found that Israel, as a warring party rather than occupying power in the Gaza Strip, does not have a duty to look after the welfare of the territory's residents, ${ }^{101}$ that the Court noted with seeming approval that Israel 'accepts and respects the rules provided in the laws of war, and is committed to continuing to supply the amount of fuel and electricity needed for the essential humanitarian needs of the civilian population in the Gaza Strip'. ${ }^{102}$

Three combining factors are alluded to by the Court in support of this implication that although Israel is not the occupying power, there nonetheless remains 'a duty on Israel to continue and provide some basic supplies to Gaza (electricity and fuels at levels needed to maintain basic humanitarian needs)'. ${ }^{103}$ The Court observed that Israel's duties derived from: (i) the situation of armed conflict between Israel and Hamas; (ii) the extent to which the State controlled border crossings between Israel and the Gaza Strip; and (iii) 'the relationship that was created between Israel and the territory of the Gaza Strip after the years of Israeli military rule in the territory, as a result of which the Gaza Strip is currently almost completely dependent upon the supply of electricity from Israel'. ${ }^{104}$ While agreeing with the ultimate finding of the Court that Gaza is not occupied, Yuval Shany is correct in his observation that 'the Court did not carefully explain the legal theory which connects (a) the factual relations that characterise the relations between Israel and Gaza; to (b) Israel's legal obligations vis-à-vis Gaza'. ${ }^{105}$

The first factor cited by the Court, the situation of armed conflict between Israel and Hamas, gives rise in law only to an obligation on Israel to allow safe passage of supplies. It implies a looser legal framework governing economic sanctions between warring parties as opposed to the more burdensome duty of care incumbent upon an occupying power. It thus does not provide a legal basis for the obligation on Israel to continue providing certain levels of fuel and electricity to Gaza. Moreover, the rudimentary determination of 'the situation of armed conflict between Israel and Hamas' leaves many unanswered questions in relation to the status of Gaza. It is unclear precisely when the Court,

100 Bassiouni Ahmed et al v Prime Minister (Judgment) (n 97) para 11.

101 Ibid para 12.

102 Ibid para 21.

103 Y Shany, 'The Law Applicable to Non-Occupied Gaza: A Comment on Bassiouni $v$ Prime Minister of Israel', Hebrew University International Law Research Paper (2009) 5. Available at SSRN: http://ssrn.com/abstract=1350307.

104 Bassiouni Ahmed et al v Prime Minister (Judgment) (n 97) para 12. The contention that reduction of fuel supply amounted to collective punishment was seemingly dismissed by the statement that 'the reduction of the fuel supply, in the controlled manner in which it is made, may damage the terrorist infrastructures and their ability to operate against the citizens of the State of Israel, considering that the amount of fuel that enters the Gaza Strip is supposed to satisfy only the humanitarian purposes that require the use of fuel', see ibid., para 4.

105 Shany (n 103) 5. 
or the State of Israel itself, considers this particular conflict to have started. Following the commencement of occupation in 1967, the conflict between Israel and the Palestinians has at various times assumed the status of an armed conflict, to which Hamas can be seen as having become a party at points since its creation during the first Palestinian intifada in 1987. While one potential position is that the broader conflict between Israel and the Palestinians may have formally ended with the signing of the Oslo Accords by Israel and the Fatah-led Palestine Liberation Organization (PLO) in the mid-1990s, events since then, including hostilities between Israel and numerous Palestinian armed groups throughout the West Bank and Gaza since the outbreak of the second intifada in 2000, demonstrate the persistence of armed conflict. ${ }^{106}$ It might alternatively be argued that not only the occupation but any existing armed conflict in Gaza came to an end by virtue of Israel's disengagement in 2005, with a new, narrower conflict between Israel and Hamas commencing upon the latter's assumption of de facto authority within Gaza in 2007. This, however, is problematic in terms of defining the status of Gaza between 2005 and 2007, during which time hostilities persisted Israel's withdrawal of ground forces notwithstanding - while the Palestinian National Authority ${ }^{107}$ continued to govern according to its limited competences under the Oslo Accords. It is also testament to the fact that in the absence of an agreed, definitive end to the occupation, the non-occupied paradigm may create a legal black hole vis-à-vis Gaza's status. The Court's classification of the situation in Gaza as a bilateral conflict between Israel and Hamas further amounts to a simplification of the reality witnessed most recently during 'Operation Cast Lead', where various Palestinian armed groups, including the Fatah-affiliated Al-Aqsa Martyrs' Brigades, engaged in hostilities with Israeli forces. ${ }^{108}$ Moreover, the Court does not address the challenging question of whether such an armed conflict is to be considered as international or non-international in nature. ${ }^{109}$

By citing the additional factors of Israel's control of Gaza's borders and the dependency of Gaza's population on Israel, it appears that the Court fabricated

106 For the position of the Israeli Supreme Court - that a 'continuous situation of armed conflict has existed since the first intifada' between Israel and the 'various' Palestinian armed groups active in the West Bank and Gaza Strip - see Public Committee v Government of Israel (n 78) para 18. See also eg Barake v The Minister of Defense, HCJ 9293/01, 56(2) PD 509; Almadani v IDF Commander in Judea \& Samaria, HCJ 3451/ 02, 56(3) PD 30, 34; Ajuriv The Military Commander of the Judea and Samaria Area, HCJ 7015/02, 56(6) PD 352, 358. See also D Kretzmer, 'Targeted Killings of Suspected Terrorists: Extra-Judicial Executions or Legitimate Means of Defence?' (2005) 16 EJIL 2 171, 205-12.

107 Which was led during that period initially by Fatah, then by Hamas following January 2006 legislative elections, and subsequently by a unity government formed in February 2007.

108 See 'Report of the UN Fact-finding Mission' (n 7) para 282: 'Military hostilities took place between the Israeli armed forces and the military wing of Hamas (al-Qassam Brigades) and of other Palestinian factions, including the al-Aqsa Martyrs' Brigades, loosely affiliated with the Fatah movement in control of the Palestine Authority.'

109 See further 'Report of the UN Fact-finding Mission' (n 7) paras 282-3; Kretzmer (n 106). 
a halfway house of obligations that are more onerous than those legally required of an enemy belligerent under humanitarian law, but less so than those that bind an occupying power. Thus the Court projects onto Israel the duty to provide a certain 'minimum' level of supplies without expounding where it perceives this duty to come from in law. The duty appears to be based on some form of lingering post-occupation moral obligation, as a way to circumvent the more stringent and concrete legal obligations held by an occupying power. There is, however, no rule of law providing for such post-occupation obligations, for the simple reason that occupations were never envisaged ending in the manner that Israel unilaterally purported to do in Gaza, but rather with a full cessation of hostilities and with a conclusive agreement for the comprehensive relinquishing of control by the occupying power. As Shany acknowledges in reflecting on the Gaza Fuel and Electricity decision:

Although the Court held that a duty to provide a minimum level of supplies exists, it did not identify in its decision any relevant rule of IHL that could serve as the basis for this positive obligation. ${ }^{110}$

Shany thus attempts to fill in the gaps and provide a legal basis for the Court's findings, on bases of extra-territorial application of international human rights law and 'moral or legal obligations' arising from the 'post-occupation situation'. ${ }^{111}$ These attempts are unconvincing, particularly in respect of the latter where the analysis speculates as to the rationale of the Court's unsubstantiated allusions to obligations arising from the historical dependency of Gaza's residents on Israel:

Perhaps, the Court meant to insinuate here that Israel had failed throughout its long occupation of Gaza to facilitate the development of local capabilities for producing basic supplies, and that, under these circumstances Israel carries a legal responsibility to remedy this omission by way of continuing to supply the essential needs of Gaza. ${ }^{112}$

Shany tentatively suggests that such a responsibility could be constructed on the basis of Israel's failure throughout its presence in Gaza to administer the infrastructure in the occupied territory in accordance with the rules of usufruct as necessitated under Article 55 of the Hague Regulations (and by consequence would remain accountable post-occupation), as well as on the basis of state responsibility considerations of equity and good neighbourliness. He ultimately admits, however, that 'such a construction appears to be far-reaching in its implications and without real support in law and practice'. ${ }^{113}$

\footnotetext{
110 Shany (n 103) 9.

111 Ibid 5.

112 Ibid 16.

113 Ibid 17.
} 
Dinstein, on the other hand, plainly disagrees with the hypothesis that Gaza is no longer occupied, and takes the view that the artificiality of this position adopted by the Israeli Government and Supreme Court is only highlighted by the Gaza Fuel and Electricity decision:

The notion that a Belligerent Party in wartime is duty bound to supply electricity and fuel to its enemy is plainly absurd. The sole reason for the existence of an obligation to ensure such supplies for the benefit of the civilian population - even at a minimal level - is that the occupation is not over. ${ }^{114}$

The Supreme Court has since been presented with opportunities to clarify its position on the contours of Israel's legal responsibilities with regard to the Gaza Strip, and to address some of the questions left unanswered by the Gaza Fuel and Electricity decision. The Court has failed to do so, however, most recently in its judgment upholding the ban imposed by the Israeli authorities on family members from Gaza visiting their relatives incarcerated in prisons in Israel. ${ }^{115}$ Here, a nine-paragraph judgment simply cited the Gaza Fuel and Electricity decision to reiterate the position that since September 2005, 'the 'belligerent occupation' on the Strip has not existed from the perspective of international law'. ${ }^{116}$

As far as the extra-territorial application of international human rights law is concerned, the principle that human rights instruments are relevant in addition to humanitarian law in the regulation of international armed conflict was entrenched by the ICJ in the $1990 \mathrm{~s},{ }^{117}$ with the normative relationship between the two bodies of law often centring around interpretation of the lex specialis rule. The Court has since confirmed the parallel application of human rights law during armed conflict, including in cases where it specifically held human rights conventions to bind States Parties acting as occupying powers extraterritorially $^{118}$ (including Israel with respect to the West Bank and Gaza ${ }^{119}$ ). While declaring this doctrine regarding human rights law in occupied territory to be inapplicable to 'non-occupied' Gaza, Shany nonetheless points to it as 'indicative of the growing flexibility of human rights law and its potential extra-territorial reach'. ${ }^{120}$ On this basis he deduces that 'the Court's decision in Bassiouni can be regarded as the outcome of an act of balancing between the human rights of Gaza residents and Israel's national interest'. ${ }^{121}$

114 Dinstein (n 17) 279.

115 Anbar et al $v$ GOC Southern Command et al, HCJ 5268/08; joined with Adalah et al $v$ the Defense Minister et al, HCJ 5399/08 (Judgment) (9 December 2009).

116 Ibid para 6.

117 Legality of the Threat or Use of Nuclear Weapons (n 26) para 25.

118 Democratic Republic of the Congo v Uganda (n 27) para 175.

119 ICJ Wall Advisory Opinion (n 58) paras 102-13.

120 Shany (n 103) 12.

121 Ibid 16. 
International human rights law is of course relevant, although notably the Supreme Court did not make any reference in the Gaza Fuel and Electricity judgment to this branch of international law or even to its concepts in regard to the relationship between Israel and the population of Gaza. The application of human rights law to territories beyond a State's borders raises questions that are distinct yet not unrelated to the issue of an occupation's existence, and relating primarily to the matter of control over persons, objects or territory. Recent ICJ jurisprudence on the matter directly linked the extra-territorial human rights obligations of Israel and Uganda to their status as occupying powers in Palestinian and Congolese territory respectively. Regarding one particular treaty, for instance, the ICJ found in the Wall opinion that:

The International Covenant on Economic, Social and Cultural Rights contains no provision on its scope of application. This may be explicable by the fact that this Covenant guarantees rights which are essentially territorial. However, it is not to be excluded that it applies both to territories over which a State party has sovereignty and to those over which that State exercises territorial jurisdiction. ${ }^{122}$

Accordingly, it was on the basis that 'the territories occupied by Israel have for over 37 years been subject to its territorial jurisdiction as the occupying Power ${ }^{\text {,123 }}$ that the Court held Israel to be bound by the Covenant in the West Bank and Gaza Strip. Jurisprudence of the European Court of Human Rights has based extra-territorial application of the European Convention for the Protection of Human Rights and Fundamental Freedoms likewise on the existence of occupation, but extending also to situations where a State exercises effective control:

the responsibility of a Contracting Party could also arise when as a consequence of military action - whether lawful or unlawful - it exercises effective control of an area outside its national territory. The obligation to secure, in such an area, the rights and freedoms set out in the Convention, derives from the fact of such control whether it be exercised directly, through its armed forces, or through a subordinate local administration. $^{124}$

122 ICJ Wall Advisory Opinion (n 58) para 112.

123 Ibid. In cases of occupied territory, Roberts advocates caution in asserting that human rights instruments should be applied absolutely. A Roberts, 'Transformative Military Occupation: Applying the Laws of War and Human Rights' (2006) 100 AJIL 580, 594.

124 Loizidou v Turkey (App No 15318/89 of 18 December 1996) (1997) 36 ILM 440, 453 para 52. See also Banković et al v Belgium and 16 other contracting states (Grand Chamber Decision on Admissibility) App No 52207/99 (19 December 2001); N Lubell, 'Challenges in Applying Human Rights Law to Armed Conflict' (2005) 87 Intl Rev Red Cross 737. 
Extra-territorial control over individual persons or building might also trigger a State's human rights obligations, as recent scholarship and jurisprudence demonstrates. $^{125}$

In the situation of Gaza, the question of the part played by international human rights law in regulating the relationship between Israel and the local population is separate from the issue of whether the territory remains occupied, although the finding of occupation would be indicative of the presence of the effective control necessary for the application of human rights law. Consideration of the potential role of human rights law in this context is a broader issue, one which is beyond the scope of this article, but it bears stating that the application of human rights law should not serve as a reason to displace the clear and established normative framework of the laws of occupation.

Given the lack of substantiated legal foundation for the Supreme Court's decision, extra-legal factors underpinning the ruling bear consideration. Clutching at the idea of obligations deriving from 'post-occupation' dependency as it did, it is likely that the Court sought to alleviate guilt (and international outcry) over the humanitarian situation that Israel's siege had created in Gaza, while at the same time absolving Israel of the responsibilities of an occupying power. Political factors may also have contributed: if not providing at least a low level of fuel and electricity to Gaza themselves, the Israeli authorities would have come under heightened pressure to allow safe passage of supplies from elsewhere as per their obligations under the laws of armed conflict, obliging them to open access to Gaza from Egypt, the West Bank and beyond. Doing so would have been at variance with the extant Israeli closure and control policy in the territory.

\section{The Continuing Exercise of Control}

There is little doubt that Israel continues to exercise considerable control over the Gaza Strip, but the question is whether such control is of the type that amounts to belligerent occupation. The existence of a local government within Gaza is among the primary factors cited as evidence of a lack of effective Israeli control, ${ }^{126}$ but this remains a somewhat blinkered approach insofar as it disregards the broader context of the control of Gaza's borders and external affairs, and the de facto prevention of the local authorities from exercising genuine sovereignty. The Israeli Supreme Court, amongst others, has emphasized the absence of any fixed Israeli military presence, government or administration in Gaza. ${ }^{127}$ It has been outlined above, however, that occupation-related jurisprudence has not insisted on either a fixed presence or formal administration, but rather that a foreign occupying power must have the power to send troops at

125 See generally N Lubell, Extraterritorial Use of Force Against Non-State Actors (OUP, Oxford 2010) 193-235.

${ }^{126}$ See eg the position of the Israeli Supreme Court in Bassiouni Ahmed et al v Prime Minister (Judgment) (n 97) para 12; Shany (n 103) 7.

127 Bassiouni Ahmed et al v Prime Minister (Judgment) (n 97) para 12. 
short notice in order to reimpose control and that it is sufficient that the local authorities are prevented from exercising full authority, even if a formal governmental administration has not been established by the occupant. The 'Goldstone Report' notes that, 'as shown in the case of Denmark during the Second World War, the occupier can leave in place an existing local administration or allow a new one to be installed for as long as it preserves for itself the ultimate authority'. ${ }^{128}$ Yoram Dinstein has asserted that Israel's 'withdrawal - while impinging on manifold practical aspects of the administration of the area - did not put paid to the overall occupation'. ${ }^{129}$ The Israeli Supreme Court itself held in the Tsemel case, relating to Israel's presence in South Lebanon, that:

The application of Part III of the Hague Regulations and the application of the parallel provisions in the Fourth [Geneva] Convention do not depend on the establishment of a particular organizational framework in the form of military administration. The duties and authorities of the military force are established and derived from the mere military control of the area. ${ }^{130}$

It also bears noting that although the system of Israeli military orders applicable to Gaza, and, by consequence, the jurisdiction of Israeli military courts therein, were repealed in accordance with the 'disengagement', this has not resulted in full authority over matters relating to the administration of justice being transferred by Israel to the Palestinians. Israel has instead enacted specific legislation in the form of the 2006 Criminal Procedure Law ${ }^{131}$ to allow it to incarcerate Palestinians from the Gaza Strip in detention facilities in Israel, and to prosecute them in Israeli civil courts. Although the discriminatory scope of application solely to non-residents of the State of Israel provided for in the original bill $^{132}$ was amended, it appears that the statute, enacted in the wake of the disengagement, was born from a desire to retain direct control over aspects of the administration of justice in Gaza, and in practice has been applied almost exclusively against Gazans, with arrests and prosecutions continuing. According to estimates submitted to the Knesset Constitution, Law and Justice Committee by the head of the investigations unit of the Israeli General Security Services (GSS) concerning the applicability of the law, '[o]ver $90 \%$ of detainees (to which this law was applied) were from the Gaza Strip'. ${ }^{133}$

128 See 'Report of the UN Fact-finding Mission' (n 7) para 279.

129 Dinstein (n 17) 15.

130 Tsemel v Minister for Defence, HCJ 102/82, cited in Shany (n 4) 376.

131 Criminal Procedure (Enforcement Powers - Detention) (Detainees Suspected of Security Offences) (Temporary Provision) Law 5765-2006.

132 Criminal Procedure (Enforcement Powers - Detention) (Non-Resident Detainees Suspected of Security Offence) (Temporary Provision) Bill 5765-2005.

133 Quoted in 'Report of the UN Fact-finding Mission' (n 7) para 1443. 
Reference must also be made to the 2002 Internment of Unlawful Combatants Law, ${ }^{134}$ originally enacted to legalize the internment of Lebanese nationals classified by the Israeli authorities as potential 'bargaining chips' for the exchange of Israeli prisoners of war and bodies. On 12 September 2005, the day that Israel completed implementation of its disengagement plan and declared the end of the military justice system in the Gaza Strip, the military authorities issued detention orders under the Internment of Unlawful Combatants Law against two Gaza residents. Since then, the law has been primarily to detain Palestinians from the Gaza Strip without trial. ${ }^{135}$ In total, pursuant to the various laws utilized by Israel post-disengagement, 751 Palestinian residents of the Gaza Strip were incarcerated in Israel as of July 2009. ${ }^{136}$

Iain Scobbie reminds us that the potential exercise of authority criterion 'was not a legal innovation created by the Yugoslav Tribunal but simply re-stated established law, following the US Military Tribunal at Nuremberg in the List case'. ${ }^{137}$ In this respect, 'Operation Cast Lead' was but the latest in a string of incursions in which Israeli troops have been able to make their authority felt within Gaza since 'disengagement'. Israel has also established 'no-go areas' and 'buffer zones' within the Gaza Strip, in areas near the border and where Israeli settlements were formerly located. Palestinian inhabitants of Gaza are prohibited from entering such areas at any time, which are strictly monitored and enforced by the Israeli armed forces. ${ }^{138}$ While it is argued that the potential to exercise control is not the same as actual control and that in the case of Gaza, any control that does exist is not effective control given the instances of rocket attacks against Israel from Gaza, established jurisprudence would appear to counter this.

The occurrence of resistance or even the resurgence of hostilities would not alter the situation of occupation, unless such was to the extent of ousting the occupier and restoring the full control of the previous sovereign; as the ICTY has stated, 'sporadic local resistance, even successful, does not affect the reality of occupation' ${ }^{139}$ By contrast, Abraham Bell has written that the establishment

134 Internment of Unlawful Combatants Law 5762-2002. This statute enables the state to carry out large-scale internment, for unlimited periods and without substantial judicial review. It was upheld as constitutional by the Supreme Court in Crim. App. [Criminal Appeal] 6659/06, Riad 'Ayad and Hassan 'Ayad v State of Israel (11 June 2008) PD 44 (1) 721. The law was then updated and amended by the Knesset on 28 July 2008 in order to expand the internment powers it grants to the Israeli authorities.

135 See B'Tselem and HaMoked, 'Without Trial: Administrative Detention of Palestinians by Israel and the Internment of Unlawful Combatants Law' (Jerusalem October 2009) 55-69.

136 Adalah, 'New Data on Palestinian Prisoners incarcerated in Israeli Prisons' (July 2009) <http://www.adalah.org/newsletter/eng/jul09/New_Prisoner_Data_july_2009. pdf $>$.

137 Scobbie (n 4) 31. As noted above, the United States of America $v$ Wilhelm List et al (n 52) is also referred to as the Hostages case.

138 See eg 'Report of the UN Fact-finding Mission' (n 7) para 278.

139 Naletilić et al (n 22) para 217. 
of effective control in Gaza would require an extensive military conquest of Gaza and that 'military superiority over a neighbor, and the ability to conquer a neighbor in an extensive military operation, does not itself constitute occupation'. ${ }^{140}$ This may be true with respect to any initial establishment of occupation in a situation of two sovereign neighbouring States, but in the context at hand Bell's discussion of military superiority wilfully ignores the previous four decades of Israel's military occupation of Gaza, the dependency that has accompanied it and the continued exercise of control over Gaza. He has also pointed out that if Israel were to be considered an occupying power, it would then be obliged to 'restore and ensure public order and safety' in Gaza under Article 43 of the Hague Regulations, which could involve intervening in internal fighting such as that which took place between Hamas and Fatah in 2007. This may be an unintended consequence of the well-intentioned efforts of intergovernmental and human rights organizations to hold Israel to obligations existing under the laws of occupation. While execution of this requirement by Israel would clearly be controversial in the current situation, such an obligation is envisaged under the laws of occupation and should only be acted upon in accordance with the protections afforded to the civilian population. The failure or unwillingness of Israel to fulfil such an obligation in accordance with the rules of international humanitarian and human rights law would not serve to deny its status as an occupying power. Shany's contention that Israel does not have the capacity to fulfil Article 43, and accordingly that 'it makes little sense from a legal policy perspective' to recognize Israel as an occupier for the purposes of Article 42, ${ }^{141}$ appears misguided, both in terms of its rationale of determining a normative question on the basis of speculation as to a practical question, and in light of Israel's capacity to assert its authority in the Gaza Strip when it so desired during 'Operation Cast Lead'. According to Dinstein:

The insistence by Israel on its liberty to retake militarily (at its discretion) any section of the Gaza Strip - and even to bring to Israel for detention or prosecution suspected saboteurs - is the most telling aspect of the nontermination of the occupation. ${ }^{142}$

If the previous forty-three years of Israeli occupation of Gaza are put aside momentarily, it is conceivable that the nature of the control exercised by Israel over Gaza, with the lack of a fixed military presence or administration, could be classified as a form of siege (including, in relation to maritime access, a naval blockade ${ }^{143}$ ) not amounting to occupation. The control of borders, airspace and coastal waters and the disruption of fuel, electricity and other supplies could amount to a situation short of belligerent occupation were it not for the other fac-

140 Bell (n 90).

141 Shany (n 103) 7.

142 Dinstein (n 17) 279.

143 See generally MG Fraunces, 'The International Law of Blockade: New Guiding Principles in Contemporary State Practice' (1992) 101 Yales LJ 893. 
tors discussed above. Even in imposing a siege or blockade, a party to an armed conflict cannot use this measure as a means of starving the civilian population, and the passage of various foodstuffs, medical goods and essential supplies must be allowed. ${ }^{144}$ One of the leading authors on the laws of occupation, Gerhard von Glahn, entertained the idea that the 'definite control' needed for occupation might be exercisable without any fixed military presence on the ground:

Needless to say, it is not necessary that the invading forces occupy every locality in the hostile area in order to establish a state of effective occupation. Since international law does not contain a rule prescribing the military arm through which an effective belligerent occupation is to be exercised, it might be theoretically possible to maintain necessary control through the occupant's air force alone. Establishment of a number of air bases, sufficient in strength to prevent invasion of the occupied territory or insurrection of its inhabitants would appear to be sufficient, as far as the writer can ascertain, to create the effective occupation demanded under the rules of international law. ${ }^{145}$

In considering this thought experiment, however, von Glahn felt that such an 'air force occupation' would likely encounter numerous 'practical problems', although he did not elaborate on what these may have been. Without doubt, from the time of his writing in 1957, and since the adoption of the Hague Regulations some fifty years prior to that, the exercise of military dominance in the air and the control of airspace have assumed a far greater significance in contemporary warfare and conflict. ${ }^{146}$ Similarly, when Spaight wrote in 1911 of the occupying power's ability to 'police' the occupied territory, ${ }^{147}$ the conception of policing a territory pertinent to that time was of course by means of forces present on the ground. Almost a century later, however, it is certainly possible for an occupying power to police a territory with minimal reliance on forces physically present on the ground, and rather through the use of sophisticated aerial, satellite and surveillance technology. In particular, 'the nature of air power, and the notion of air superiority have been transformed in the past few years by the rise of remotecontrolled drone technology'. ${ }^{148}$ Israel's military is at the forefront of such technological advancements, second only to the United States in terms of development and possession of drones, or 'unmanned aerial vehicles' (UAVs). In

144 See eg AP I 1125 UNTS 3 (n 93) arts 54 and 70. As noted previously, the obligations incumbent on an occupying power regarding the provision of food, medicine and essential supplies are even more onerous. See eg GCIV art 55 and API art 69.

$145 \mathrm{G}$ von Glahn The Occupation of Enemy Territory: A Commentary on the Law and Practice of Belligerent Occupation (University of Minnesota Press, Minneapolis 1957) 28-9 [footnotes omitted].

146 See Scobbie (n 4).

147 Spaight (n 48).

148 --, 'Attack of the Drones' Economist: Technology Quarterly (5 September 2009) 15. 
2008-2009 alone, 'the Israeli Defence Forces' fleet of UAVs has tripled in size'. ${ }^{149}$ In the absence of the fixed presence of ground troops, this fleet is of paramount importance to Israel in Gaza, where it keeps complete control of the airspace through continuous surveillance by its aircraft and UAVs. ${ }^{150}$

International humanitarian law and much of the judicial and scholarly commentary on the question of occupation has tended to focus more on when an occupation is said to begin, rather than when it has ended. While many of the criteria for the former could simply be the reverse for the latter, concluding that a multifaceted occupation of a territory's land, air and waters can be terminated by the redeployment of the occupying forces' land troops appears to be an overly simplistic and formalistic claim, based on somewhat outdated concepts of land warfare as the dominant form. In the specific context of Gaza, it has been noted that 'the situation is not one of creating an occupation, which as a practical matter would appear to require the use of ground forces to create and maintain control, but rather is whether an existing occupation has been terminated or maintained'. ${ }^{151}$ Adam Roberts advises that 'the withdrawal of occupying forces is not the sole criterion of the ending of an occupation; and the occupant has not necessarily withdrawn at the end of all occupations'. ${ }^{152}$ One is also reminded of Lawrence's assertion that once established, an occupation will remain 'until the occupier is completely dispossessed'. ${ }^{153}$

If we consider the conditions put forward by Gerhard von Glahn, that 'military occupation ends through permanent and voluntary withdrawal of the occupying forces, through forceful and lasting ejection of the occupant either by a native uprising or by regular enemy forces, or through provisions of an armistice or peace treaty at the end of the conflict', ${ }^{154}$ it seems that these criteria have not been fully met in Gaza. The withdrawal of Israeli troops was voluntary, but not permanent, given the incursions and operations that have taken place since September 2005; it is doubtful that resistance in Gaza led to an ejection of Israeli troops, which in any event has not been lasting; and, finally, the 'disengagement' was a unilateral act that was not part of a final peace agreement between the parties to the conflict, which would be the usual, although not exclusive means for termination of occupation. The 'hostile territory' declaration does not carry any legal significance from the perspective of international humanitarian law, but

149 Ibid. See C Downes, 'Targeted Killings' in an Age of Terror: The Legality of the Yemen Strike' (2004) 9 JCSL 277.

150 'Report of the UN Fact-finding Mission' (n 7) para 278. That such a strategy of air control has been purposefully pursued by the Israeli military is clear from statements such as that of by Major General Amos Yadlin, then head of Israeli military intelligence, in 2004: 'Our vision of air control zeroes in on the notion of control. We're looking at how you control a city or a territory from the air when it's no longer legitimate to hold or occupy that territory on the ground.' Quoted in B Opall-Rome, 'Israel AF Wants Wider Role in Anti-Terror War' Defense News (5 January 2004).

151 Scobbie (n 4) 6-7.

152 A Roberts, 'The End of Occupation: Iraq 2004' (2005) 54 ICLQ 27, 28.

153 Lawrence (n 46) 436 [emphasis added].

154 von Glahn (n 145) 30 [footnote omitted]. 
can be seen perhaps as part of a process whereby the Israeli Government seeks to distance itself from its legal obligations as an occupying power.

The conclusion that Gaza remains occupied territory and that Israel remains an occupying power there, with all the obligations that flow from relevant conventional and customary international humanitarian law, is supported by international opinion as well as reality on the ground. ${ }^{155}$ Gaza, along with the West Bank, has certainly been subject to a prolonged military occupation by Israel since 1967. The argument might be made that given the treatment of the Palestinian territories within the Green Line as a single political unit for the purposes of peace negotiations ${ }^{156}$ and the exercise of the Palestinian right to self-determination, ${ }^{157}$ any uncertainty regarding Gaza should be resolved by reference to the West Bank remaining occupied territory, although it is not inconceivable that there could be partial occupation of territory. ${ }^{158}$ While Israel transferred to the Palestinian Authority a series of functions within designated zones in the West Bank and Gaza Strip under the Oslo Accords, it retained significant 'powers and responsibilities not so transferred'. ${ }^{159}$ When Israeli troops and settlements were subsequently withdrawn from Gaza, a pre-existing Palestinian local administration was left in place and there is no local governing body to which full authority has been transferred. The ICJ held that the transfer of powers and responsibilities by Israel under the various agreements with the PLO has 'done nothing' to alter the status of Israel as an occupying power. ${ }^{160}$ The commentary to the Fourth Geneva Convention confirms that in relation to prolonged occupations it was envisaged that there could be a gradual transfer of powers to the occupied power while the occupation continues and without its status being altered. ${ }^{161}$ Thus, the United Nations Security Council stressed during 'Operation Cast Lead' that 'the Gaza Strip constitutes an integral part of the territory occupied in 1967 and will be a part of the Palestinian state'. ${ }^{162}$

Israel continues to exert considerable control over Gaza in the form of physical control of borders, coastal waters and airspace; administrative control of the population registry and ID system; and fiscal control of taxes, customs duties and VAT. The flow of people and goods into and out of the territory remains at the

155 See above (ns 6-8).

156 As agreed by Israel and the Palestine Liberation Organisation in the Oslo Accords. See 'Declaration of Principles on Interim Self-Government Arrangements (13 September 1993) Art IV; and 'Israeli-Palestinian Interim Agreement on the West Bank and the Gaza Strip' (28 September 1995) Article XI.1. The Israeli Supreme Court has also previously held that the West Bank and Gaza Strip must be viewed as one occupied territory. See eg Ajuri v Commander of IDF Forces in the West Bank (Judgment) HCJ 7015/02 (3 September 2002).

157 ICJ Wall Advisory Opinion (n 58) para 118; UNSC Res 1860 (n 6).

158 See Shany (n 4) 380.

159 Israeli-Palestinian Interim Agreement on the West Bank and the Gaza Strip (1995) Art I.1.

160 ICJ Wall Advisory Opinion (n 58) para 78.

161 Pictet (n 57) 62-3.

162 UNSC Res 1860 (n 6). 
discretion of the Israeli authorities, while under the 'disengagement plan' the inhabitants of Gaza are still reliant on Israeli currency for economic transactions. Israel also continues to control Gaza's telecommunications, water and sewage networks, as well as the supply of fuel, electricity and other supplies. Dinstein rightly concludes that 'Israel has not lost or relinquished diverse core elements of effective control'. ${ }^{163}$ This continuing control is highly significant in the context of the situation of dependency that has been created in Gaza, as acknowledged by the Israeli Supreme Court.

Several authoritative judicial decisions have set forth criteria for the existence of occupation which do not exclude the possibility of an occupation in the absence of a fixed troop presence or military administration. The situation in Gaza poses a challenge to traditional understandings of the concept of occupation in some ways, but in many ways it conforms to the principal age-old requirement of control:

as long as the territory as a whole is in the power and under the control of the occupant and as long as the latter has the ability to make his will felt everywhere in the territory within a reasonable time, the military occupation exists from a legal point of view. ${ }^{164}$

\section{Conclusion}

The debate over the legal status of Gaza can be seen to be primarily about the extent of Israel's legal obligations towards the territory and its population. By denying that Gaza is an occupied territory, but agreeing to allow provisions for basic needs, Israel has sought to reduce its obligations under the laws of armed conflict, and the question of provision then becomes an issue of political will rather than of international obligation. In light of prior lack of good faith in the application of international humanitarian law to the Palestinian territories, the 'disengagement' bears the hallmark of an attempt by Israel to abrogate its legal responsibilities. International law itself is being manipulated in this equation. Daniel Reisner, the former head of the Israeli military's International Law Division, stated in the wake of 'Operation Cast Lead' that '[i]f you do something for long enough, the world will accept it ... International law progresses through violations'. ${ }^{165}$ The approach of the Israeli government to the situation in Gaza seems to comport with its view that changes are needed to the rules of international humanitarian law, in order to 'back up the IDF and grant it freedom to act'. 166

163 Dinstein (n 17) 278.

164 von Glahn (n 145) 28-9 [footnotes omitted].

165 Quoted in Y Feldman and U Blau, 'Consent and Advise' Ha'aretz (Israel 29 January 2009).

166 Quoted in R Sofer, 'Netanyahu: Advance International Effort to Change Laws of War' Yediot Aharonot (20 October 2009). 
The 'disengagement' process is viewed as having been intentionally designed to reduce friction with the population of Gaza while maintaining effective control and accordingly of being "closer to an enhanced "redeployment" of troops than an end to occupation'. ${ }^{167}$ It is difficult to see how a State that has occupied a territory for over forty years and which exercises control over the means of providing for the local population, as well as the ability of any existing authority to do so effectively, can deny its status as an occupying power. On the basis of a presumption that the fundamental aim of international humanitarian law is the protection of civilians, in cases where the existence of occupation has been disputed or ambiguous, jurisprudence of the ICTY and domestic courts has displayed a clear tendency to lean towards a positive determination of occupation. ${ }^{168}$ The Israeli Supreme Court digressed from that tendency in the Gaza Fuel and Electricity case, with dubious grounds for doing so, and while scholars may tender legal arguments to fill the analytical void left by the Supreme Court, much of the reasoning proffered is tenuous or derived from undeveloped norms. In the absence of a viable and legally sound alternative normative paradigm, the threshold for termination of an occupation will remain high, such that the law errs on the side of greater protection, and that occupying powers in an inherent position of power are precluded from unilaterally deciding the extent of their own legal obligations.

The abuse of international legal rules, as well as the acute failure of both Israel and the Palestinian factions to fulfil their obligations to investigate and prosecute alleged crimes perpetrated by their forces, are indicative of a legal culture of evasion and manipulation, rather than compliance. Attempts to situate the Gaza Strip in a legal limbo, no longer occupied but not yet sovereign, are a further manifestation of such evasion. While events in Gaza have departed from traditional conceptions of warfare and occupation, and international humanitarian law's own limitations have been exposed by the many grey areas that arise in its application therein, sufficient clarity is retained when it comes to the effective control exercised by Israel over the Gaza Strip in order to categorize the territory as occupied. Embedded in the law is an assumption that occupation is a temporary situation which all parties to a conflict are to work in good faith towards remedying, as part of an agreed upon and sustainable resolution of the conflict. Otherwise and until that occurs, the Gaza Strip will remain occupied territory for the purposes of international humanitarian law.

167 Mari (n 4) 366.

168 See Naletilic (n 22) para 221 regarding the adjudged maintenance of occupation as: 'Otherwise civilians would be left, during an intermediate period, with less protection than that attached to them once occupation is established'. See also $R$ ( $A l$ Skeini) v Secretary of State for Defence [2005] 2 WLR 1401 where it was held that even if not in full effective control of Basra at the relevant time, the UK was to be considered an occupying power for the purposes of applying the protections of the Fourth Geneva Convention. 